\title{
Convergence and Divergence of Signaling Events in Guard Cells during Stomatal Closure by Plant Hormones or Microbial Elicitors
}

\author{
Srinivas Agurla and Agepati S. Raghavendra * \\ Department of Plant Sciences, School of Life Sciences, University of Hyderabad, Hyderabad, India
}

\section{OPEN ACCESS}

Edited by:

Girdhar Kumar Pandey, University of Delhi, India

Reviewed by:

Chun-Peng Song,

Henan University, China

Gaurav Zinta,

Shanghai Center for Plant Stress

Biology (PSC), China

Francesca Sparla,

University of Bologna, Italy

*Correspondence:

Agepati S. Raghavendra as_raghavendra@yahoo.com: asrs/s@gmail.com

Specialty section: This article was submitted to Plant Physiology, a section of the journal Frontiers in Plant Science

Received: 24 April 2016 Accepted: 05 August 2016

Published: 24 August 2016

Citation: Agurla S and Raghavendra AS (2016)

Convergence and Divergence of Signaling Events in Guard Cells during Stomatal Closure by Plant Hormones or Microbial Elicitors.

Front. Plant Sci. 7:1332. doi: 10.3389/fpls.2016.01332
Dynamic regulation of stomatal aperture is essential for plants to optimize water use and $\mathrm{CO}_{2}$ uptake. Stomatal opening or closure is accompanied by the modulation of guard cell turgor. Among the events leading to stomatal closure by plant hormones or microbial elicitors, three signaling components stand out as the major converging points. These are reactive oxygen species (ROS), cytosolic free $\mathrm{Ca}^{2+}$, and ion channels. Once formed, the ROS and free $\mathrm{Ca}^{2+}$ of guard cells regulate both downstream and upstream events. A major influence of ROS is to increase the levels of $\mathrm{NO}$ and cytosolic free $\mathrm{Ca}^{2+}$ in guard cells. Although the rise in $\mathrm{NO}$ is an important event during stomatal closure, the available evidences do not support the description of $\mathrm{NO}$ as the point of convergence. The rise in $\mathrm{ROS}$ and $\mathrm{NO}$ would cause an increase of free $\mathrm{Ca}^{2+}$ and modulate ion channels, through a network of events, in such a way that the guard cells lose $\mathrm{K}^{+} / \mathrm{Cl}^{-}$/anions. The efflux of these ions decreases the turgor of guard cells and leads to stomatal closure. Thus, $\mathrm{ROS}, \mathrm{NO}$, and cytosolic free $\mathrm{Ca}^{2+}$ act as points of divergence. The other guard cell components, which are modulated during stomatal closure are G-proteins, cytosolic pH, phospholipids, and sphingolipids. However, the current information on the role of these components is not convincing so as to assign them as the points of convergence or divergence. The interrelationships and interactions of ROS, $\mathrm{NO}$, cytosolic $\mathrm{pH}$, and free $\mathrm{Ca}^{2+}$ are quite complex and need further detailed examination. Our review is an attempt to critically assess the current status of information on guard cells, while emphasizing the convergence and divergence of signaling components during stomatal closure. The existing gaps in our knowledge are identified to stimulate further research.

Keywords: ABA, cytosolic free $\mathrm{Ca}^{2+}$, cytosolic $\mathrm{pH}$, ROS, guard cells, ion channels, nitric oxide, secondary messengers

\section{INTRODUCTION}

Stomata are tiny pores found on the leaf surface of higher plants, which facilitate the evaporation of $\mathrm{H}_{2} \mathrm{O}$ via transpiration and intake of $\mathrm{CO}_{2}$ for photosynthetic carbon assimilation (Acharya and Assmann, 2009). Stomata are also major points of entry for pathogens into the plants (Melotto et al., 2006, 2008). Therefore, the regulation of stomatal aperture is essential for limiting the loss of $\mathrm{H}_{2} \mathrm{O}$ as well as restricting pathogen entry. The guard cells are quite sensitive to several internal and external stimuli, including abiotic (drought, light, temperature, high $\mathrm{CO}_{2}$, humidity) or 
biotic factors (pathogens and elicitors). Plant hormones (such as abscisic acid, ABA, methyl jasmonate, MJ) and polyamines (PAs) induce stomatal closure. Elicitors such as salicylic acid (SA), chitosan, and Flg22 also cause stomatal closure (Alcázar et al., 2010; Jing et al., 2012; Gayatri et al., 2013; Ye et al., 2013; Agurla et al., 2014). Stomata open when guard cells are turgid and close when the guard cells are flaccid (Blatt, 2000). During stomatal opening, guard cells accumulate osmotically active components, such as potassium ions, anions, malate and sucrose, leading a decrease in water potential, influx of water, and increase in turgor. In contrast, the reversal of these events leads to flaccidity in guard cells and stomatal closure (Vavasseur and Raghavendra, 2005; Bright et al., 2006; Roelfsema et al., 2012).

Among several effectors, the effects of ABA (a phytohormone) on stomatal movements have been studied in detail. ABA induced stomatal closure is mediated by many signaling components like cytoplasmic $\mathrm{pH}$, reactive oxygen species (ROS), reactive nitrogen species (nitric oxide, $\mathrm{NO}$ ), cytosolic free $\mathrm{Ca}^{2+}, \mathrm{G}-$ proteins, protein kinases, protein phosphatases, phospholipids, phospholipases, and sphingolipids (Wang and Song, 2008; Raghavendra et al., 2010; Umezawa et al., 2010; García-Mata and Lamattina, 2013; Song et al., 2014). The diverse spectrum of signaling components during stomatal closure have been reviewed frequently (Kim et al., 2010; Joshi-Saha et al., 2011; Gayatri et al., 2013; Agurla et al., 2014; Kollist et al., 2014; Song et al., 2014; Murata et al., 2015; Lee et al., 2016).

There are yet questions about the sequence of the signaling events during stomatal closure. For e.g., cytosolic free $\mathrm{Ca}^{2+}$ may act at either downstream or upstream of ROS/NO. The changes in cytosolic $\mathrm{pH}$ of guard cells may be important at either downstream or upstream of ROS or NO. The production of NO precedes that of ROS, but NO can act as antioxidant as well. Despite these ambiguities, it is clear that a rise in ROS or NO triggers a rise in free $\mathrm{Ca}^{2+}$ of guard cells, modulate the ion channels and cause an efflux of $\mathrm{K}^{+} / \mathrm{Cl}^{-} /$malate, leading to loss in turgor of guard cells. We emphasize that the signaling events during stomatal closure converge at ROS, cytosolic $\mathrm{Ca}^{2+}$, and ion channels. Similarly, ROS, NO, and $\mathrm{Ca}^{2+}$ form the points of divergence.

\section{Points of Convergence: ROS, Cytosolic Free $\mathrm{Ca}^{2+}$, and lon Channels}

When guard cells are exposed to signals originating from abiotic or biotic factors the process of signal transduction is initiated. During this process, three points can be recognized as those of convergence: ROS, cytosolic free $\mathrm{Ca}^{2+}$, and anion channels. For e.g., plant hormones (such as ABA or MJ) and microbial elicitors invariably cause an increase in the levels of ROS or NO in guard cells, leading to rise in free $\mathrm{Ca}^{2+}$ within the guard cells (Table 1). There are excellent reviews, emphasizing the role of ROS (Kollist et al., 2014; Song et al., 2014; Murata et al., 2015), NO (Hancock et al., 2011; García-Mata and Lamattina, 2013; Gayatri et al., 2013; Agurla et al., 2014), and cytosolic free $\mathrm{Ca}^{2+}$ in guard cells (Kim et al., 2010; Roelfsema and Hedrich, 2010). Hormones and elicitors interact with different receptor entities, but the subsequent steps converge to activate NADPH oxidase, increase ROS, NO, and $\mathrm{Ca}^{2+}$ in guard cells (Figure 1). Although $\mathrm{NO}$ in guard cells is a key signaling component, there is no sufficient evidence to describe it as point of convergence. While it is clear that ROS can cause an increase in NO of guard cells, no other components that can raise NO levels has been described.

\section{Reactive Oxygen Species (ROS)}

A marked rise in ROS of guard cells is a consistent feature of stomatal closure induced by ABA, MJ, and even microbial elicitors (Zhang H. et al., 2009; Song et al., 2014). While the effect of ABA on NADPH oxidase is mediated by ABA-receptorsprotein phosphatase interactions (Raghavendra et al., 2010), the mechanism of NADPH oxidase stimulation by elicitors is ambiguous. Certain MAP kinases activated by elicitors could in turn activate NADPH oxidase (Zhang H. et al., 2009).

There has been overwhelming evidence that NADPH oxidase is the major ROS source in ABA, MJ, or SA induced stomatal closure. However, the source of ROS may not always be NADPH oxidase, as ROS production in response to elicitors, such as SA, yeast elicitor, and chitosan can occur through a salicylhydroxamic acid (SHAM) sensitive peroxidase or amine oxidases (e.g., copper amine oxidase or polyamine oxidase) (Khokon et al., 2011; Gao et al., 2013; Murata et al., 2015). During stomatal closure induced by methylglyoxal (MG), isothiocyanates or thiocyanates, the rise in ROS of Arabidopsis guard cells was mediated by a SHAM sensitive peroxidase (Hoque et al., 2012; Hossain et al., 2013). Activation of NADPH oxidase can occur also by phosphatidic acid (PA) (Zhang H. et al., 2009). Thus, the ROS of guard cells is a major point of convergence. The ROS production by different systems, involving NADPH oxidase or peroxidase has been reviewed recently by Murata et al. (2015).

\section{Cytosolic Free Calcium}

Calcium $\left(\mathrm{Ca}^{2+}\right)$ is an important secondary messenger during stomatal closure (McAinsh et al., 1990; Hubbard et al., 2012). The role of $\mathrm{Ca}^{2+}$ is confirmed by monitoring of $\mathrm{Ca}^{2+}$ in guard cells by fluorescent probes, the $\mathrm{Ca}^{2+}$ chelators, and $\mathrm{Ca}^{2+}$ channel blockers (Pei et al., 2000; Kim et al., 2010). The rise in $\mathrm{Ca}^{2+}$, due to influx or release from internal sources like endoplasmic reticulum, further activates anion channels and inhibits the $\mathrm{K}_{\mathrm{in}}^{+}$ channels, all leading to stomatal closure. There are suggestions that $\mathrm{Ca}^{2+}$ may act also upstream of ROS and NO (GarciaMata et al., 2003). In contrast, Zhang et al. (2011) observed that calcium channels functioned downstream of $\mathrm{H}_{2} \mathrm{O}_{2}$ in G-protein $\alpha$-subunit (gpa1) mutants. In gpal mutants, ABA-induced ROS production was disrupted, but $\mathrm{Ca}^{2+}$ channels were activated by exogenous $\mathrm{H}_{2} \mathrm{O}_{2}$ application.

\section{Ion Channels}

The ion channels represent the last step of signal transduction, leading to stomatal closure. The ionic status driven by the activity of cation/anion channels determines the turgor state of guard cells. Rise in free $\mathrm{Ca}^{2+}$ of guard cells causes the efflux of $\mathrm{K}^{+} / \mathrm{Cl}^{-}$/other ions. The detailed descriptions of ion channels, their intracellular location, encoding genes, along with mutants are made in a few reviews (Hedrich, 2012; Roelfsema et al., 2012; Kollist et al., 2014). Plants have several types of $\mathrm{K}^{+}$channels, 
TABLE 1 | Major points of convergence as well as divergence during signal transduction leading to stomatal closure by hormones or elicitors.

\begin{tabular}{lll}
\hline Convergence & Upstream component & References \\
\hline ROS & & \\
& NADPH oxidase & Kwak et al., 2003 \\
& Peroxidase & Khokon et al., 2010 \\
& Copper amine oxidase & An et al., 2008 \\
G-protein alpha subunit (GPA) & Zhang et al., 2011 \\
& OST1 protein kinase & Mustilli et al., 2002 \\
& Cytosolic free Ca2+ & Kobayashi et al., 2007 \\
& Phosphatidic acid & Zhang et al., 2004 \\
& MAPK & Meng and Zhang, 2013 \\
PI3K/PI4K & Park et al., 2003 \\
S1P & Ma et al., 2012 \\
PA Phospholipase D $\alpha 1$ & Zhang Y. et al., 2009 \\
Cytosolic pH & Suhita et al., 2004
\end{tabular}

CYTOSOLIC FREE $\mathrm{Ca}^{2+}$

ROS

Pei et al., 2000

NO

Hossain et al., 2014

Inositol 1,4,5-trisphosphate

Gilroy et al., 1990

Cyclic ADP ribose

Leckie et al., 1998

Calcineurin-B like proteins

Drerup et al., 2013

ION CHANNELS

$\mathrm{Ca}_{\text {in }}^{2+}$ channels

$$
\mathrm{Ca}^{2+}
$$

Mori et al., 2006

Garcia-Mata et al., 2003

Inward-rectifying $\mathrm{K}^{+}$channels (KAT1)

$$
\begin{aligned}
& \mathrm{PA} \\
& \text { Cytosolic free } \mathrm{Ca}^{2+} \\
& \mathrm{NO}
\end{aligned}
$$

Outward rectifying $\mathrm{K}^{+}$channel (GORK)

$$
\begin{aligned}
& \mathrm{pH} \\
& \text { Cytosolic free } \mathrm{Ca}^{2+} \\
& \mathrm{NO}
\end{aligned}
$$

Uraji et al., 2012

Grabov and Blatt, 1999

Sokolovski and Blatt, 2004

Hosy et al., 2003

Pei et al., 1998

Sokolovski and Blatt, 2004

Slow anion channel 1 (SLAC1)

MAPK9/12

Danquah et al., 2014

Cytosolic free $\mathrm{Ca}^{2+}$

Geiger et al., 2010

Slow anion channel Homolog 3 (SLAH3)
Cytosolic free $\mathrm{Ca}^{2+}$

Quick anion channels (QUAC1/ALMT6) OST1

\section{Geiger et al., 2010}

Engineer et al., 2016

\begin{tabular}{lll}
\hline Divergence & Downstream component & References \\
\hline ROS & & \\
& NO & Bright et al., 2006 \\
& MAPK9/12 & Jammes et al., 2009 \\
& Cytosolic free Ca ${ }^{2+}$ & Pei et al., 2000 \\
& Cytosolic pH & Zhang et al., 2001 \\
NO & PLD $\delta$ & \\
& Cytosolic free $\mathrm{Ca}^{2+}$ & Distéfano et al., 2012 \\
& Cytosolic free $\mathrm{Ca}_{\text {in }}^{2+}$ & Zhao et al., 2013 \\
& & Garcia-Mata et al., 2003 \\
\hline
\end{tabular}

(Continued)
TABLE 1 | Continued

\begin{tabular}{cl}
\hline $\begin{array}{c}\mathrm{K}_{\text {in }}^{+} \text {channels } \\
\mathrm{K}_{\text {out }}^{+} \text {channels }\end{array}$ & Garcia-Mata et al., 2003 \\
CYTOSOLIC FREE Ca & Solovski and Blatt, 2004 \\
NADPH oxidase & Kimura et al., 2012 \\
NO & Garcia-Mata and Lamattina, \\
& 2007 \\
Cytosolic pH & Islam et al., 2010 \\
SLAC1 & Laanemets et al., 2013 \\
SLAH3 & Geiger et al., 2011
\end{tabular}

The convergence is illustrated by the multiple upstream elements leading to an increase in the given component. Similarly, the divergence occurs when multiple components are modulated by the given signaling element. An illustration is given in Figure 1.

$R O S$, reactive oxygen species; NO, nitric oxide; MAPK, mitogen-activated protein kinases; SLAC1, slow anion channel-associated 1; SLAH3, slow anion channel homolog 3; $\mathrm{Ca}^{2+}$, calcium; $\mathrm{H}_{2} \mathrm{O}_{2}$, hydrogen peroxide; $K_{\text {in }}$ channel, $K^{+}$inward rectifying channel; $K_{\text {out }}$ channel, $K^{+}$outward rectifying channel; PA, phosphatidic acid; OST1, open stomata 1; QUAC1, quick anion channel 1; ALMT, aluminum activated malate transporters; PLD, phospholipase D; S1P, sphingosine-1-phosphate.

which can allow either inward or outward movement of $\mathrm{K}^{+}$. The $\mathrm{K}_{\text {in }}^{+}$channels open up, when the membrane potential becomes hyperpolarized. In contrast, outward-rectifying $\mathrm{K}^{+}$channels $\left(\mathrm{K}_{\text {out }}^{+}\right)$open when the membrane potential is depolarized.

Guard cell $\mathrm{Ca}^{2+}$-permeable cation channels are stimulated by $\mathrm{H}_{2} \mathrm{O}_{2}$ and $\mathrm{NO}$, whose levels are raised by $\mathrm{ABA}$ or $\mathrm{MJ}$ during stomatal closure (Mori et al., 2006; Rienmüller et al., 2010). Elevated free $\mathrm{Ca}^{2+}$ in guard cells can be due to the activation of $\mathrm{Ca}^{2+}$ channels in not only plasma membrane but also vacuolar or internal membrane network. The activation of ion channels would promote efflux of malate and other anions make the guard cells lose turgor and cause stomatal closure. But, there is considerable ambiguity on the relative dominance and specificity of different ion channels. Guard cells are known to contain slow anion channel-associated 1 (SLAC), quick anion channel 1 (QUAC), slow anion channel homolog 3 (SLAH), and even aluminum activated malate transporters (ALMT) (Roelfsema et al., 2012). Further work is required to elucidate the role of each of these different types of anion channels and their interactions.

\section{Points of Divergence: ROS, NO, and Cytosolic Free $\mathrm{Ca}^{2+}$}

The rise in levels of ROS, NO, or cytosolic free $\mathrm{Ca}^{2+}$ in guard cells trigger multiple events downstream (Table 1). The ability to induce diverse effects makes these three signaling components qualified to be the points of divergence (Figure 1). The rise in ROS of guard cells initiates several downstream events: NO production, elevation of cytosolic free $\mathrm{Ca}^{2+}$, and rise in cytosolic pH (Wang and Song, 2008; Song et al., 2014). Kinetic studies indicated that ROS production was prior to the NO production (Gonugunta et al., 2008). The positioning of the ROS was further confirmed by using Arabidopsis mutants and hydrogen-rich water (HRW) (Xie et al., 2014). The impaired NO synthesis and stomatal closure in response by HRW and rescue of closure by exogenous application of NO in rbohF mutant indicated that ROS functioned as an upstream signaling component. The importance of ROS in NO production was also demonstrated 


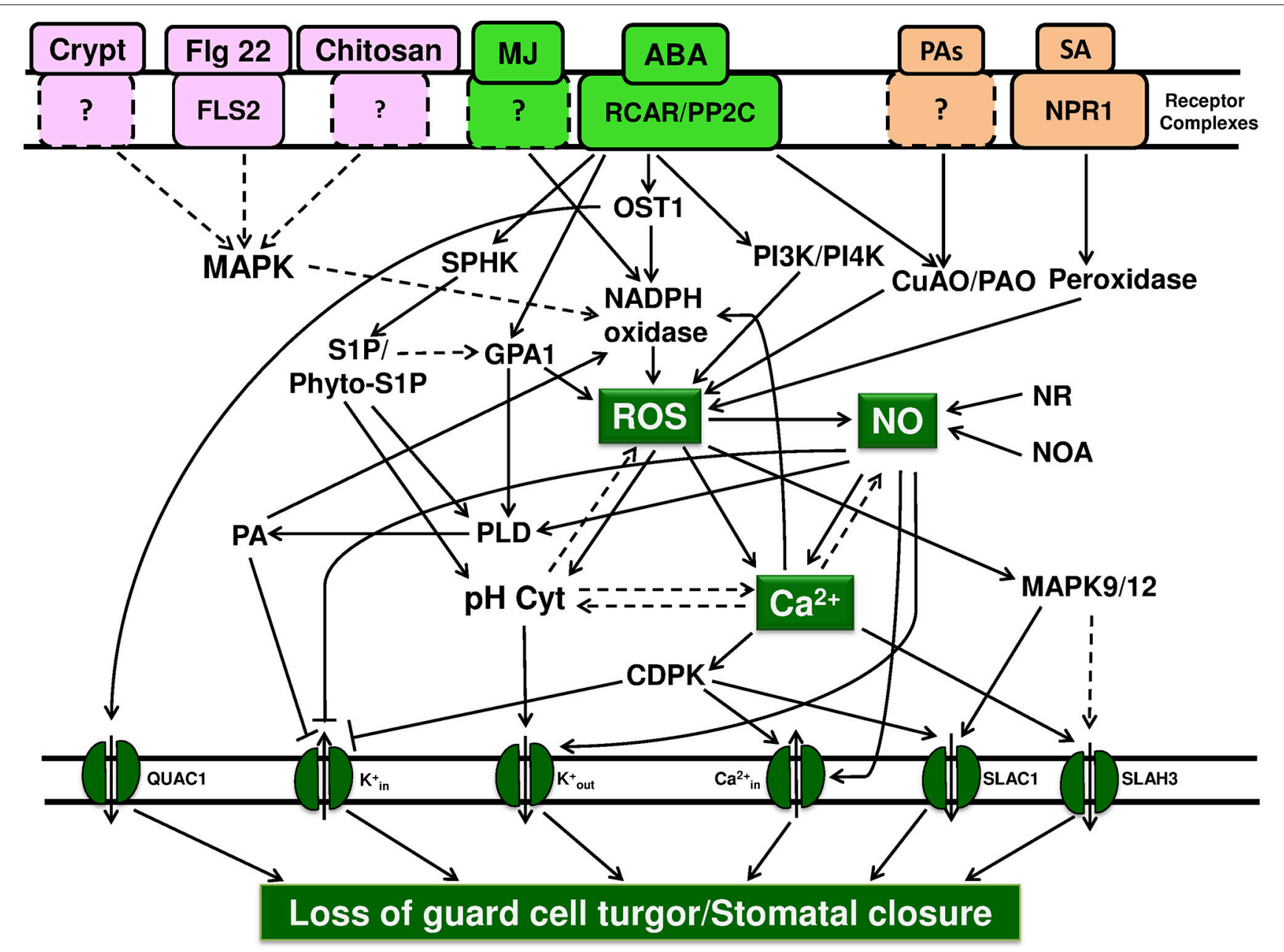

FIGURE 1 | Key points of convergence and divergence during stomatal closure in response to plant hormones and elicitors. Stomatal closure is the result of ion efflux out of guard cells, loss of their turgor, and forms the ultimate step during signal transduction. We suggest that ROS, cytosolic free $\mathrm{Ca}^{2+}$, and ion channels form points of convergence during stomatal closure by a variety of abiotic/abiotic factors. Similarly, ROS, NO, and cytosolic $\mathrm{Ca}^{2+}$ are identified as points of divergence. The activation of NADPH oxidase and ROS production are among the earliest events. Similarly, the modulation of ion channels, influx of free $\mathrm{Ca}^{2+}$ along with efflux of $\mathrm{K}^{+}$and anions, are the final steps, leading to the loss of ions/turgor of guard cells. The binding of ABA to RCAR/PYR or Flg22 to FLS2 or SA to S-receptor are well established, while receptors of cryptogein, chitosan, and PAs are yet to be characterized. ROS: When ABA binds to the receptor (RCAR/PYR/PYL), PP2C becomes non-functional, leading to phosphorylation, and activation of OST1 protein kinase. The elevated kinase activity along with $\mathrm{Ca}^{2+}$, activates NADPH oxidase, and subsequently elevates ROS production. Besides NADPH oxidase, CUAO/PAO are also involved in the increase of ROS in guard cells. The levels of ROS can be elevated by also peroxidase, for e.g., upon salicylic acid binding to its receptor. Further, G-protein alpha subunit induces the ROS production through the activation of NADPH oxidase. Modulation of ROS levels by NO, cytosolic $\mathrm{Ca}^{2+}$, cytosolic $\mathrm{pH}$ can occur by direct or indirect mechanisms but these reactions need to be established. Cytosolic free $\mathrm{Ca}^{2+}$ : the rise in the levels of ROS and NO, can increase the levels of cytosolic free $\mathrm{Ca}^{2+}$, by either release of $\mathrm{Ca}^{2+}$ from internal stores or influx of external $\mathrm{Ca}^{2+}$ through plasma membrane $\mathrm{Ca}_{\text {in }}^{2+}$ channels. $\mathrm{Ca}^{2+}$ also activates SLAH3 and SLAC1 ion channels, while inhibiting $\mathrm{K}_{\text {in }}^{+}$ion channels. lon channels: the modulation of cation/anion channels results in the net efflux of $\mathrm{K}^{+} / \mathrm{Cl}^{-} /$malate and influx of $\mathrm{Ca}^{2+}$, making guard cells to lose turgor and causing stomatal closure. NO: NR, nitrate reductase; NOA, nitric oxide associated 1 are the sources of $\mathrm{NO}$. Although there are suggestions that ROS, cytosolic $\mathrm{Ca}^{2+}$ or cytosolic $\mathrm{pH}$ can elevate $\mathrm{NO}$ levels, the mechanism is not known. The rise in NO leads to divergent actions, namely the rise in cytosolic $\mathrm{Ca}^{2+}$, activation of PLD, and subsequently NADPH oxidase. Further, NO activates $\mathrm{K}_{\text {out }}^{+}$ion channels, inhibits $\mathrm{K}^{+}$channels, and activates $\mathrm{Ca}_{\mathrm{in}}^{2+}$ ion channels. Other components: The role of cytosolic $\mathrm{pH}$ is not completely understood. The available evidence suggests that the cytosolic $\mathrm{pH}$ may act parallely with the events involving ROS/NO/cytosolic free $\mathrm{Ca}^{2+}$. Similarly, G-proteins, phospholipids, phospholipases, phosphatidyl inositol kinases, sphingolipids, and MAP kinases also act in such a way to cause the loss of turgor in guard cells and stomatal closure. Solid arrows represent the events which are documented, while broken arrows represent the possible effects/suggestions.

in mutants deficient in G-proteins and nitrate reductase (Bright et al., 2006; He et al., 2013).

Nitric oxide (NO) is a small, gaseous molecule involved in growth, development and even disease resistance of plants (Domingos et al., 2015). Studies using modulators (scavengers/inhibitors/donors) of NO production emphasized the importance of NO during stomatal closure (Gayatri et al., 2013; Agurla et al., 2014). NO production in guard cells of Arabidopsis and Vicia faba is essential for stomatal closure by SA and yeast elicitor (Sun et al., 2010; Khokon et al., 2011). Real time 
monitoring studies suggested that $\mathrm{NO}$ acted as a downstream signaling component to the ROS as well as $\mathrm{pH}$ (Gonugunta et al., 2008; Srivastava et al., 2009). Nitric oxide synthase (NOS) is the source of NO in animal cells, but the presence/operation of NOS in plant cells is quite uncertain. Both nitrate reductase (NR) and NOA1 (nitric oxide associated) are shown to be the sources of NO in guard cells of V. faba and Arabidopsis (Hao et al., 2010; Gao et al., 2013).

The interaction of $\mathrm{NO}$ with the other signaling components is quite crucial (Gayatri et al., 2013). In guard cells, NO can cause multiple effects, namely rise in internal $\mathrm{Ca}^{2+}$, cytosolic alkalization, and activation of $\mathrm{K}_{\text {out }}^{+}$channels (Gonugunta et al., 2008; Jing et al., 2010). NO is also essential for the elevation of the signaling components, like PLD $\alpha 1$ and PLD $\delta$, during PA induced stomatal closure (Distéfano et al., 2008, 2010; Uraji et al., 2012).

The components of downstream signaling by $\mathrm{Ca}^{2+}$ in guard cells are quite intriguing. The changes in $\mathrm{Ca}^{2+}$ are sensed and mediated by the different types of intracellular calcium binding proteins like calmodulins, calcium dependent protein kinases (CDPKs, particularly, CPK3, and CPK6) and calcium sensing receptors (CAS) (Mori et al., 2006). $\mathrm{Ca}^{2+}$-dependent CPK6, CPK21, and CPK23 activate SLAC1 in oocytes (Geiger et al., 2010; Brandt et al., 2012). In contrast, $\mathrm{Ca}^{2+}$-independent protein kinases like OST1 are involved in ABA activation of intracellular calcium channels (Murata et al., 2015). $\mathrm{Ca}^{2+}$. independent SnRK2 protein kinases such as OST1, have been shown to activate SLAC1 in Xenopus leavis oocytes (Geiger et al., 2009; Lee et al., 2009; Brandt et al., 2012). Such $\mathrm{Ca}^{2+}$ activation of S-type anion currents is an early and essential step during stomatal closure (Siegel et al., 2009; Chen et al., 2010).

\section{Other Components Cytosolic pH}

Cytoplasmic $\mathrm{pH}$ is a signaling component in developmental processes, such as root growth (Scott and Allen, 1999). A marked rise in cytoplasmic $\mathrm{pH}$ is a common feature during stomatal closure by ABA, MJ, elicitors, and even S1P (Suhita et al., 2004; Gonugunta et al., 2008). Cytosolic alkalization and production of NO in the guard cells and stomatal closure were observed on exposure to ethephon (source of ethylene) and pyrabactin (Jing et al., 2010; Puli and Raghavendra, 2012). Similarly, darkness or ultraviolet $\mathrm{B}$ (UV-B) exogenous $\mathrm{Ca}^{2+}$ induced stomatal closure was also accompanied by the increase in cytoplasmic pH and ROS (Ma et al., 2013; Zhu et al., 2014). In a reverse of the situation, fusicoccin (a fungal phytotoxin, produced by Fusicoccum amygdale) induced stomatal opening, by causing cytoplasmic acidification, and lowering of NO levels, even in presence of ABA (Huang et al., 2013).

Among the upstream components leading to the alkalization of cytoplasm in guard cells are the elevated ROS, PA/PLD, NO, and $\mathrm{S} 1 \mathrm{P} /$ phytoS1P. However, the exact trigger of guard cell alkalization on exposure to $\mathrm{ABA}$ or $\mathrm{MJ}$ or elicitors and the downstream events of cytoplasmic $\mathrm{pH}$ change are not clear. A possibility is that on cytoplasmic alkalization, the $\mathrm{K}_{\text {out }}^{+}$channels are activated, triggering $\mathrm{K}^{+}$efflux and collapse of turgor in guard cells (Blatt and Armstrong, 1993). Cytosolic alkalization needs to coordinate with the increase in cytosolic free $\mathrm{Ca}^{2+}$ during ABA or MJ induced stomatal closure (Islam et al., 2010). Unlike the role of ROS, NO, and cytosolic $\mathrm{Ca}^{2+}$ as points of convergence and divergence, the action of cytoplasmic $\mathrm{pH}$ seems to be parallel. Further experiments are needed to make cytoplasmic $\mathrm{pH}$ qualified to be called as a point of convergence.

\section{G-Proteins}

Although the modulation of heterotrimeric $G$ proteins is known to be an important component leading to stomatal closure, the exact mode of G-protein action is ambiguous. Ge et al. (2015) suggested that ethylene induced stomatal closure was mediated through $\mathrm{G} \alpha$ induced ROS production in Arabidopsis thaliana. In similar case, Arabidopsis gpal mutants, deficient in G-protein $\alpha$ subunit, are impaired in $\mathrm{Ca}^{2+}$-channel activation, and ROS production, in response to ABA (Zhang et al., 2011). G-proteins were essential for the production of ROS as well as NO during the effects of UV-B irradiation or external $\mathrm{Ca}^{2+}$ (Li et al., 2009; Zhang et al., 2012; He et al., 2013). Most of these evidences suggest that G-proteins induce an increase in the levels of ROS in guard cells. It is not clear if ROS production is due to or independent of NADPH oxidase.

\section{Phospho- and Sphingolipids}

Phosphatidic acid (PA), the product of phospholipase C/D (PLC/PLD) induced stomatal closure by inhibiting $\mathrm{K}_{\text {in }}^{+}$channel in the guard cells, besides interacting with ABI1 and activating NADPH oxidase (Jacob et al., 1999; Zhang et al., 2004). NO induced stomatal closure was restricted by PLC/PLD inhibitors (Distéfano et al., 2008), suggesting that PA acts downstream of the NO during stomatal closure in $V$. faba. Furthermore, ABA-induced NO production was impaired in pld $\alpha 1$ mutant guard cells (Distéfano et al., 2008). Phosphoshingolipids such as sphingosine-1-phosphate (S1P) and phytosphingosine-1phosphate (phytoS1P) regulate multiple functions in plants besides stomatal closure (Ng et al., 2001; Coursol et al., 2005; Puli et al., 2016). ABA activates sphingosine kinases (SHPKs), leading to the production of S1P. However, our knowledge of downstream signaling components of S1P is limited (Coursol et al., 2003).

\section{Interactions among Signaling Components and with Environmental Factors}

Signaling components, particularly ROS and NO, play an important role in not only stomatal closure but also in integrating stimuli from abiotic or biotic stress (Song et al., 2014; Saxena et al., 2016). The marked interactions between ROS, NO, $\mathrm{Ca}^{2+}$, and $\mathrm{pH}$ are pointed out (Zhang et al., 2001; Gonugunta et al., 2009; Song et al., 2014). ROS and NO interact with each other and can increase cytosolic $\mathrm{Ca}^{2+}$ and modulate ion channels. However, the feedback relationship between NO and ROS is obscure. Similarly, cytoplasmic $\mathrm{pH}$ may act directly on ion channels, particularly $\mathrm{K}_{\text {out }}^{+}$or indirectly by modulating ROS and/or NO, yet the mechanism of such action is not completely clear. Further, $\mathrm{Ca}^{2+}$ also can interact with $\mathrm{NO}$ and $\mathrm{pH}$ (Wang et al., 2011; Gayatri et al., 2013). It is likely that ABA plays a key role in these interactions. Endogenous $\mathrm{ABA}$ is involved during MJ-induced stomatal closure (Munemasa et al., 2007, 2011; Ye 
et al., 2013). Both the $\mathrm{Ca}^{2+}$-dependent and $\mathrm{Ca}^{2+}$-independent signaling pathways are considered to function during stomatal closure (Kim et al., 2010; Roelfsema et al., 2012). However, the interrelationships of such $\mathrm{Ca}^{2+}$-dependent and independent pathways during guard cell signal transduction are yet to be elucidated.

Interactions of guard cell signaling components with environmental factors are not only interesting but are essential for adaptation. Drought raises the levels of ROS and ABA levels in plant tissues, with both these phenomena leading to stomatal closure (Saxena et al., 2016). The effects of $\mathrm{CO}_{2}$ induced stomatal closure can also be mediated by ABA (Chater et al., 2015). Further experiments are needed to identify the exact link between $\mathrm{CO}_{2}$ and ABA. An increase in ROS due to elevated CO2 in guard cells (Kolla et al., 2007) could raise the endogenous ABA levels and amplify the signaling events leading to stomatal closure. Similar involvement and interactions of ROS, NO, and $\mathrm{pH}$ are reported during UV-B induced stomatal closure (He et al., 2013; Zhu et al., 2014).

\section{CONCLUDING REMARKS}

The patterns and action sequence of signaling components during stomatal closure have been worked out using different triggers, such as ABA, MJ, and chitosan (Gonugunta et al., 2009). Both plant hormones or microbial elicitors cause an increase in $\mathrm{ROS}, \mathrm{NO}, \mathrm{pH}$, and free $\mathrm{Ca}^{2+}$ of guard cells, modulate ion channels, and cause an efflux of $\mathrm{K}^{+} / \mathrm{Cl}^{-} /$malate from guard cells,

\section{REFERENCES}

Acharya, B. R., and Assmann, S. M. (2009). Hormone interactions in stomatal function. Plant Mol. Biol. 69, 451-462. doi: 10.1007/s11103-008-9427-0

Agurla, S., Gayatri, G., and Raghavendra, A. S. (2014). Nitric oxide as a secondary messenger during stomatal closure as a part of plant immunity response against pathogens. Nitric Oxide 43, 89-96. doi: 10.1016/j.niox.2014.07.004

Alcázar, R., Altabella, T., Marco, F., Bortolotti, C., Reymond, M., Koncz, C., et al. (2010). Polyamines: molecules with regulatory functions in plant abiotic stress tolerance. Planta 231, 1237-1249. doi: 10.1007/s00425-010-1130-0

An, Z., Jing, W., Liu, Y., and Zhang, W. (2008). Hydrogen peroxide generated by copper amine oxidase is involved in abscisic acid-induced stomatal closure in Vicia faba. J. Exp. Bot. 59, 815-825. doi: 10.1093/jxb/erm370

Blatt, M. R. (2000). Cellular signaling and volume control in stomatal movements in plants. Annu. Rev. Cell Dev. Biol. 16, 221-241. doi: 10.1146/annurev. cellbio.16.1.221

Blatt, M. R., and Armstrong, F. (1993). $\mathrm{K}^{+}$channels of stomatal guard cells: abscisic-acid evoked control of the outward rectifier mediated by cytoplasmic pH. Planta 191, 330-341. doi: 10.1007/BF00195690

Brandt, B., Brodsky, D. E., Xue, S., Negi, J., Iba, K., Kangasjärvi, J., et al. (2012). Reconstitution of abscisic acid activation of SLAC1 anion channel by CPK6 and OST1 kinases and branched ABI1 PP2C phosphatase action. Proc. Natl. Acad. Sci. U.S.A. 109, 10593-10598. doi: 10.1073/pnas.1116590109

Bright, J., Desikan, R., Hancock, J. T., Weir, I. S., and Neill, S. J. (2006). ABAinduced $\mathrm{NO}$ generation and stomatal closure in Arabidopsis are dependent on $\mathrm{H}_{2} \mathrm{O}_{2}$ synthesis. Plant J. 45, 113-122. doi: 10.1111/j.1365-313X.2005. 02615.x

Chater, C., Peng, K., Movahedi, M., Dunn, J. A., Walker, H. J., Liang, Y. K., et al. (2015). Elevated $\mathrm{CO}_{2}$-induced responses in stomata require $\mathrm{ABA}$ and ABA signaling. Curr. Biol. 25, 2709-2716. doi: 10.1016/j.cub.2015. 09.013 leading to stomatal closure. We emphasize that ROS, cytosolic $\mathrm{Ca}^{2+}$, and ion channels are the points of convergence (Figure 1). The cytosolic $\mathrm{pH}, \mathrm{G}$-proteins, and phospho-/sphingolipids are also important components during stomatal closure but they may be acting in parallel. Further work required to elucidate the perception of signals, such as methyl jasmonate or elicitors and how they activate NADPH oxidase leading to ROS production. Several of the unresolved questions make the stomatal guard cells an ideal system for studying signal transduction mechanism in plant cells.

\section{AUTHOR CONTRIBUTIONS}

AR proposed the topic. AR and AS collected the literature, critically assessed the information, and wrote the manuscript together.

\section{ACKNOWLEDGMENTS}

Our work on stomatal guard cells is supported by grants to AR of a JC Bose National Fellowship (No. SR/S2/JCB06/2006) from the Department of Science and Technology and another from Department of Biotechnology (No. BT/PR9227/PBD/16/748/2007), both in New Delhi. SA is supported by a Senior Research Fellowship of University Grants Commission. We also thank DBT-CREBB, DSTFIST, and UGC-SAP for support of infrastructure in Department/School.
Chen, Z. H., Hills, A., Lim, C. K., and Blatt, M. R. (2010). Dynamic regulation of guard cell anion channels by cytosolic free $\mathrm{Ca}^{2+}$ concentration and protein phosphorylation. Plant J. 61, 816-825. doi: 10.1111/j.1365-313X.2009.04108.x

Coursol, S., Fan, L. M., Stunff, H. L., Spiegel, S., Gilroy, S., Assmann, S. M., et al. (2003). Sphingolipid signalling in Arabidopsis guard cells involves heterotrimeric G proteins. Nature 423, 651-654. doi: 10.1038/nature01643

Coursol, S., Stunff, H., Lynch, D. V., Gilroy, S., Assmann, S. M., Spiegel, S., et al. (2005). Arabidopsis sphingosine kinase and the effects of phytosphingosine1-phosphate on stomatal aperture. Plant Physiol. 137, 724-737. doi: 10.1104/pp.104.055806

Danquah, A., de Zelicourt, A., Colcombet, J., and Hirt, H. (2014). The role of ABA and MAPK signaling pathways in plant abiotic stress responses. Biotechnol. Adv. 32, 40-52. doi: 10.1016/j.biotechadv.2013.09.006

Distéfano, A. M., García-Mata, C., Lamattina, L., and Laxalt, A. M. (2008). Nitric oxide-induced phosphatidic acid accumulation: a role for phospholipases $\mathrm{C}$ and D in stomatal closure. Plant Cell Environ. 31, 187-194. doi: 10.1111/j.13653040.2007.01756.x

Distéfano, A. M., Lanteri, M. L., ten Have, A., García-Mata, C., Lamattina, L., and Laxalt, A. M. (2010). Nitric oxide and phosphatidic acid signaling in plants. Plant Cell Monogr. 16, 223-242. doi: 10.1007/978-3-642-03873-0_15

Distéfano, A. M., Scuffi, D., García-Mata, C., Lamattina, L., and Laxalt, A. M. (2012). Phospholipase $\mathrm{D} \delta$ is involved in nitric oxide-induced stomatal closure. Planta 236, 1899-1907. doi: 10.1007/s00425-012-1745-4

Domingos, P., Prado, A. M., Wong, A., Gehring, C., and Feijo, J. A. (2015). Nitric oxide: a multitasked signaling gas in plants. Mol. Plant. 8, 506-520. doi: 10.1016/j.molp.2014.12.010

Drerup, M. M., Schlücking, K., Hashimoto, K., Manishankar, P., Steinhorst, L., Kuchitsu, K., et al. (2013). The calcineurin B-like calcium sensors CBL1 and CBL9 together with their interacting protein kinase CIPK26 regulate the Arabidopsis NADPH oxidase RBOHF. Mol. Plant. 6, 559-569. doi: $10.1093 / \mathrm{mp} / \mathrm{sst} 009$ 
Engineer, C. B., Hashimoto-Sugimoto, M., Negi, J., Israelsson-Nordström, M., Azoulay-Shemer, T., Rappel, W. J., et al. (2016). $\mathrm{CO}_{2}$ sensing and $\mathrm{CO}_{2}$ regulation of stomatal conductance: advances and open questions. Trends Plant Sci. 21, 16-30. doi: 10.1016/j.tplants.2015.08.014

Gao, J., Wang, N., and Wang, G. X. (2013). Saccharomyces cerevisiae induced stomatal closure mainly mediated by salicylhydroxamic acidsensitive peroxidases in Vicia faba. Plant Physiol. Biochem. 65, 27-31. doi: 10.1016/j.plaphy.2013.01.008

Garcia-Mata, C., Gay, R., Sokolovski, S., Hills, A., Lamattina, L., and Blatt, M. R. (2003). Nitric oxide regulates $\mathrm{K}^{+}$and $\mathrm{Cl}^{-}$channels in guard cells through a subset of abscisic acid-evoked signaling pathways. Proc. Natl. Acad. Sci. U.S.A. 100, 11116-11121. doi: 10.1073/pnas. 1434381100

Garcia-Mata, C., and Lamattina, L. (2007). Abscisic acid (ABA) inhibits light-induced stomatal opening through calcium-and nitric oxide-mediated signaling pathways. Nitric Oxide 17, 143-151. doi: 10.1016/j.niox.2007. 08.001

García-Mata, C., and Lamattina, L. (2013). Gasotransmitters are emerging as new guard cell signaling molecules and regulators of leaf gas exchange. Plant Sci. 201-202, 66-73. doi: 10.1016/j.plantsci.2012.11.007

Gayatri, G., Agurla, S., and Raghavendra, A. S. (2013). Nitric oxide in guard cell as an important second messenger during stomatal closure. Front. Plant Sci. 4:425. doi: 10.3389/fpls.2013.00425

Ge, X.-M., Cai, H.-L., Lei, X., Zhou, X., Yue, M., He, J.-M., et al. (2015). Heterotrimeric $G$ protein mediates ethylene-induced stomatal closure via hydrogen peroxide synthesis in Arabidopsis. Plant J. 82, 138-150. doi: $10.1111 /$ tpj.12799

Geiger, D., Maierhofer, T., Al-Rasheid, K. A., Scherzer, S., Mumm, P., Liese, A., et al. (2011). Stomatal closure by fast abscisic acid signaling is mediated by the guard cell anion channel SLAH3 and the receptor RCAR1. Sci. Signal. 4, ra32. doi: 10.1126/scisignal.2001346

Geiger, D., Scherzer, S., Mumm, P., Marten, I., Ache, P., Matschi, S., et al. (2010). Guard cell anion channel SLAC1 is regulated by CDPK protein kinases with distinct $\mathrm{Ca}^{2+}$ affinities. Proc. Natl. Acad. Sci. U.S.A. 107, 8023-8028. doi: $10.1073 /$ pnas. 0912030107

Geiger, D., Scherzer, S., Mumm, P., Stange, A., Marten, I., Bauer, H., et al. (2009). Activity of guard cell anion channel SLAC1 is controlled by drought-stress signaling kinase phosphatase pair. Proc. Natl. Acad. Sci. U.S.A. 106, 21425-21430. doi: 10.1073/pnas.09120 21106

Gilroy, S., Read, N. D., and Trewavas, A. J. (1990). Elevation of cytoplasmic calcium by caged calcium or caged inositol trisphosphate initiates stomatal closure. Nature 346, 769-771. doi: 10.1038/346769a0

Gonugunta, V. K., Srivastava, N., Puli, M. R., and Raghavendra, A. S. (2008). Nitric oxide production occurs after cytosolic alkalinization during stomatal closure induced by abscisic acid. Plant Cell Environ. 31, 1717-1724. doi: 10.1111/j.1365-3040.2008.01872.x

Gonugunta, V. K., Srivastava, N., and Raghavendra, A. S. (2009). Cytosolic alkalinization is a common and early messenger preceding the production of ROS and NO during stomatal closure by variable signals, including abscisic acid, methyl jasmonate and chitosan. Plant Signal. Behav. 4, 561-564. doi: 10.4161/psb.4.6.8847

Grabov, A., and Blatt, M. R. (1999). A steep dependence of inward-rectifying potassium channels on cytosolic free calcium concentration increase evoked by hyperpolarization in guard cells. Plant Physiol. 119, 277-288. doi: 10.1104/pp.119.1.277

Hancock, J. T., Neill, S. J., and Wilson, I. D. (2011). Nitric oxide and ABA in the control of plant function. Plant Sci. 181, 555-559. doi: 10.1016/j.plantsci.2011.03.017

Hao, F., Zhao, S., Dong, H., Zhang, H., Sun, L., and Miao, C. (2010). Nial and $\mathrm{Nia} 2$ are involved in exogenous salicylic acid-induced nitric oxide generation and stomatal closure in Arabidopsis. J. Integr. Plant Biol. 52, 298-307. doi: 10.1111/j.1744-7909.2010.00920.x

He, J.-M., Ma, X.-G., Zhang, Y., Sun, T.-F., Xu, F.-F., Chen, Y.-P., et al. (2013). Role and inter- relationship of $\mathrm{G} \alpha$ protein, hydrogen peroxide, and nitric oxide in ultraviolet B-induced stomatal closure in Arabidopsis leaves. Plant Physiol. 161, 1570-1583. doi: 10.1104/pp.112.211623

Hedrich, R. (2012). Ion channels in plants. Physiol. Rev. 92, 1777-1811. doi: 10.1152/physrev.00038.2011
Hoque, T. S., Uraji, M., Ye, W., Hossain, M. A., Nakamura, Y., and Murata, Y (2012). Methylglyoxal-induced stomatal closure accompanied by peroxidasemediated ROS production in Arabidopsis. J. Plant Physiol. 169, 979-986. doi: 10.1016/j.jplph.2012.02.007

Hossain, M. A., Ye, W., Munemasa, S., Nakamura, Y., Mori, I. C., and Murata, Y. (2014). Cyclic adenosine $5^{\prime}$-diphosphoribose (cADPR) cyclic guanosine $3^{\prime}, 5^{\prime}$ monophosphate positively function in $\mathrm{Ca}^{2+}$ elevation in methyl jasmonateinduced stomatal closure, CADPR is required for methyl jasmonate-induced ROS accumulation NO production in guard cells. Plant Biol. 16, 1140-1144. doi: $10.1111 / \mathrm{plb} .12175$

Hossain, M. S., Ye, W., Hossain, M. A., Okuma, E., Uraji, M., Nakamura, Y., et al. (2013). Glucosinolate degradation products, isothiocyanates, nitriles, and thiocyanates, induce stomatal closure accompanied by peroxidase-mediated reactive oxygen species production in Arabidopsis thaliana. Biosci. Biotechnol. Biochem. 77, 977-983. doi: 10.1271/bbb.120928

Hosy, E., Vavasseur, A., Mouline, K., Dreyer, I., Gaymard, F., Porée, F., et al. (2003). The Arabidopsis outward $\mathrm{K}^{+}$channel GORK is involved in regulation of stomatal movements and plant transpiration. Proc. Natl. Acad. Sci. U.S.A. 100, 5549-5554. doi: 10.1073/pnas.0733970100

Huang, A. X., She, X. P., Zhang, Y. Y., and Zhao, J. L. (2013). Cytosolic acidification precedes nitric oxide removal during inhibition of ABA induced stomatal closure by fusicoccin. Russ. J. Plant Physiol. 60, 60-68. doi: $10.1134 / \mathrm{S} 1021443712060076$

Hubbard, K. E., Siegelm, R. S., Valerio, G., Brandt, B., and Schroeder, J. I. (2012). Abscisic acid and $\mathrm{CO}_{2}$ signaling via calcium sensitivity priming in guard cells, new CDPK mutant phenotypes and a method for improved resolution of stomatal stimulus-response analyses. Ann. Bot. 109, 5-17. doi: $10.1093 / \mathrm{aob} / \mathrm{mcr} 252$

Islam, M. M., Hossain, M. A., Jannat, R., Munemasa, S., Nakamura, Y., Mori, I. C., et al. (2010). Cytosolic alkalization and cytosolic calcium oscillation in Arabidopsis guard cells response to ABA and MeJA. Plant Cell Physiol. 51, 1721-1730. doi: 10.1093/pcp/pcq131

Jacob, T., Ritchie, S., Assmann, S. M., and Gilroy, S. (1999). Abscisic acid signal transduction in guard cells is mediated by phospholipase D activity. Proc. Natl. Acad. Sci. U.S.A. 96, 12192-12197. doi: 10.1073/pnas.96.21.12192

Jammes, F., Song, C., Shin, D., Munemasa, S., Takeda, K., Gu, D., et al. (2009). MAP kinases MPK9 and MPK12 are preferentially expressed in guard cells and positively regulate ROS mediated ABA signaling. Proc. Natl. Acad. Sci. U.S.A. 106, 20520-20525. doi: 10.1073/pnas.0907205106

Jing, L., Hua, L. G., Xia, H. L., and Xin, L. (2010). Ethylene-induced nitric oxide production and stomatal closure in Arabidopsis thaliana depending on changes in cytosolic pH. Chin. Sci. Bull. 55, 2403-2409. doi: 10.1007/s11434-010-4033-3

Jing, L., Zhi-hui, H., Guo-hua, L., Li-xia, H., and Xin, L. (2012). Hydrogen sulphide may function downstream of nitric oxide in ethylene induced stomatal closure in Vicia faba L. J. Integr. Agric. 11, 1644-1653. doi: 10.1016/S20953119(12)60167-1

Joshi-Saha, A., Valon, C., and Leung, J. (2011). Brand new START: abscisic acid perception and transduction in the guard cell. Sci. Signal. 4, re4. doi: 10.1126/scisignal.2002164

Khokon, M. A. R., Hossain, M. A., Munemasa, S., Uraji, M., Nakamura, Y., Mori, I. C., et al. (2010). Yeast elicitor-induced stomatal closure and peroxidasemediated ROS production in Arabidopsis. Plant Cell Physiol. 51, 1915-1921. doi: 10.1093/pcp/pcq145

Khokon, M. A. R., Okuma, E., Hossain, M. A., Munemasa, S., Uraji, M., Nakamura, Y., et al. (2011). Involvement of extracellular oxidative burst in salicylic acidinduced stomatal closure in Arabidopsis. Plant Cell Environ. 34, 434-443. doi: 10.1111/j.1365-3040.2010.02253.x

Kim, T. H., Böhmer, M., Hu, H., Nishimura, N., and Schroeder, J. I. (2010). Guard cell signal transduction network: advances in understanding abscisic acid, $\mathrm{CO}_{2}$, and $\mathrm{Ca}^{2+}$ signaling. Annu. Rev. Plant Biol. 61, 561-591. doi: 10.1146/annurevarplant-042809-112226

Kimura, S., Kaya, H., Kawarazaki, T., Hiraoka, G., Senzaki, E., Michikawa, M., et al. (2012). Protein phosphorylation is a prerequisite for the $\mathrm{Ca}^{2+}$-dependent activation of Arabidopsis NADPH oxidases and may function as a trigger for the positive feedback regulation of $\mathrm{Ca}^{2+}$ and reactive oxygen species. Biochim. Biophys. 1823, 398-405. doi: 10.1016/j.bbamcr.2011.09.011

Kobayashi, M., Ohura, I., Kawakita, K., Yokota, N., Fujiwara, M., Shimamoto, K., et al. (2007). Calcium-dependent protein kinases regulate the production of 
reactive oxygen species by potato NADPH oxidase. Plant Cell 19, 1065-1080. doi: $10.1105 /$ tpc.106.048884

Kolla, V. A., Vavasseur, A., and Raghavendra, A. S. (2007). Hydrogen peroxide production is an early event during bicarbonate induced stomatal closure in abaxial epidermis of Arabidopsis. Planta 225, 1421-1429. doi: 10.1007/s00425006-0450-6

Kollist, H., Nuhkat, M., and Roelfsema, M. R. (2014). Closing gaps: linking elements that control stomatal movement. New Phytol. 203, 44-62. doi: 10.1111/nph.12832

Kwak, J. M., Mori, I. C., Pei, Z. M., Leonhardt, N., Torres, M. A., Dangl, J. L., et al. (2003). NADPH oxidase AtrbohD and AtrbohF genes function in ROS-dependent ABA signalling in Arabidopsis. EMBO J. 22, 2623-2633. doi: 10.1093/emboj/cdg277

Laanemets, K., Wang, Y. F., Lindgren, O., Wu, J., Nishimura, N., Lee, S., et al. (2013). Mutations in the SLAC1 anion channel slow stomatal opening and severely reduce $\mathrm{K}^{+}$uptake channel activity via enhanced cytosolic $\mathrm{Ca}^{2+}$ and increased $\mathrm{Ca}^{2+}$ sensitivity of $\mathrm{K}^{+}$uptake channels. New Phytol. 197, 88-98. doi: 10.1111/nph.12008

Leckie, C. P., McAinsh, M. R., Allen, G. J., Sanders, D., and Hetherington, A. M. (1998). Abscisic acid-induced stomatal closure mediated by cyclic ADPribose. Proc. Natl. Acad. Sci. U.S.A. 95, 15837-15842. doi: 10.1073/pnas.95.26. 15837

Lee, S. C., Lan, W., Buchanan, B. B., and Luan, S. (2009). A protein kinasephosphatase pair interacts with an ion channel to regulate ABA signaling in plant guard cells. Proc. Natl. Acad. Sci. U.S.A. 106, 21419-21424. doi: 10.1073/pnas.0910601106

Lee, Y., Kim, Y. J., Kim, M. H., and Kwak, J. M. (2016). MAPK cascades in guard cell signal transduction. Front. Plant Sci. 7:80. doi: 10.3389/fpls.2016.00080

Li, J.-H., Liu, Y.-Q., Lü, P., Lin, H.-F., Bai, Y., Wang, X.-C. et al. (2009). A signaling pathway linking nitric oxide production to heterotrimeric $G$ protein and hydrogen peroxide regulates extra cellular calmodulin induction of stomatal closure in Arabidopsis. Plant Physiol. 150, 114-124. doi: 10.1104/pp.109. 137067

Ma, Y., She, X., and Yang, S. (2012). Sphingosine-1-phosphate (S1P) mediates darkness-induced stomatal closure through raising cytosol $\mathrm{pH}$ and hydrogen peroxide $\left(\mathrm{H}_{2} \mathrm{O}_{2}\right)$ levels in guard cells in Vicia faba. Sci. China Life. Sci. 55, 974-983. doi: 10.1007/s11427-012-4386-8

Ma, Y., She, X., and Yang, S. (2013). Cytosolic alkalization-mediated $\mathrm{H}_{2} \mathrm{O}_{2}$ and NO production are involved in darkness induced stomatal closure in Vicia faba. Can. J. Plant Sci. 93, 119-130. doi: 10.4141/cjps2012-040

McAinsh, M. R., Brownlee, C., and Hetherington, A. M. (1990). Abscisic acidinduced elevation of guard cell cytosolic $\mathrm{Ca}^{2+}$ precedes stomatal closure. Nature 343, 186-188. doi: 10.1038/343186a0

Melotto, M., Underwood, W., and He, S. Y. (2008). Role of stomata in plant innate immunity and foliar bacterial diseases. Annu. Rev. Phytopathol. 46, 101-122. doi: 10.1146/annurev.phyto.121107.104959

Melotto, M., Underwood, W., Koczan, J., Nomura, K., and He, S. Y. (2006). Plant stomata function in innate immunity against bacterial invasion. Cell 126, 969-980. doi: 10.1016/j.cell.2006.06.054

Meng, X., and Zhang, S. (2013). MAPK cascades in plant disease resistance signaling. Annu. Rev. Phytopathol. 51, 245-266. doi: 10.1146/annurev-phyto082712-102314

Mori, I. C., Murata, Y., Yang, Y., Munemasa, S., Wang, Y. F., Andreoli, S., et al. (2006). CDPKs CPK6 and CPK3 function in ABA regulation of guard cell Stype anion channels and $\mathrm{Ca}^{2+}$ permeable channels and stomatal closure. PLoS Biol. 4, 1749-1762. doi: 10.1371/journal.pbio.0040327

Munemasa, S., Mori, I. C., and Murata, Y. (2011). Methyl jasmonate signaling and signal crosstalk between methyl jasmonate and abscisic acid in guard cells. Plant Signal. Behav. 6, 939-941. doi: 10.4161/psb.6.7.15439

Munemasa, S., Oda, K., Watanabe-Sugimoto, M., Nakamura, Y., Shimoishi, Y., and Murata, Y. (2007). The coronatine-insensitive 1 mutation reveals the hormonal signaling interaction between abscisic acid and methyl jasmonate in Arabidopsis guard cells. Specific impairment of ion channel activation and second messenger production. Plant Physiol. 143, 1398-1407. doi: 10.1104/pp.106.091298

Murata, Y., Mori, I. C., and Munemasa, S. (2015). Diverse stomatal signaling and the signal integration mechanism. Annu. Rev. Plant Biol. 66, 21.1-21.24. doi: 10.1146/annurev-arplant-043014-114707
Mustilli, A. C., Merlot, S., Vavasseur, A., Fenzi, F., and Giraudat, J. (2002). Arabidopsis OST1 protein kinase mediates the regulation of stomatal aperture by abscisic acid and acts upstream of reactive oxygen species production. Plant Cell 14, 3089-3099. doi: 10.1105/tpc.007906

Ng, C. K. Y., Carr, K., McAinsh, M. R., Powell, B., and Hetherington, A. M. (2001). Drought-induced guard cell signal transduction involves sphingosine1-phosphate. Nature 410, 596-599. doi: 10.1038/35069092

Park, K. Y., Jung, J. Y., Park, J., Hwang, J. U., Kim, Y. W., Hwang, I., et al. (2003). A role for phosphatidylinositol 3-phosphate in abscisic acid-induced reactive oxygen species generation in guard cells. Plant Physiol. 132, 92-98. doi: 10.1104/pp.102.016964

Pei, Z. M., Baizabal-Aguirre, V. M., Allen, G. J., and Schroeder, J. I. (1998). A transient outward-rectifying $\mathrm{K}^{+}$channel current down-regulated by cytosolic $\mathrm{Ca}^{2+}$ in Arabidopsis thaliana guard cells. Proc. Natl. Acad. Sci. U.S.A. 95, 6548-6553. doi: 10.1073/pnas.95.11.6548

Pei, Z. M., Murata, Y., Benning, G., Thomine, S., Klusener, B., Allen, G. J., et al. (2000). Calcium channels activated by hydrogen peroxide mediate abscisic acid signalling in guard cells. Nature 406, 731-734. doi: 10.1038/35021067

Puli, M. R., and Raghavendra, A. S. (2012). Pyrabactin, an ABA agonist, induced stomatal closure and changes in signaling components of guard cells in abaxial epidermis of Pisum sativum. J. Exp. Bot. 63, 1349-1356. doi: 10.1093/jxb/err364

Puli, M. R., Rajsheel, P., Aswani, V., Agurla, S., Kuchitsu, K., and Raghavendra, A. S. (2016). Stomatal closure induced by phytosphingosine-1-phosphate and sphingosine-1-phosphate depends on nitric oxide and $\mathrm{pH}$ of guard cells in Pisum sativum. Planta. doi: 10.1007/s00425-016-2545-z. [Epub ahead of print].

Raghavendra, A. S., Gonugunta, V. K., Christmann, A., and Grill, E. (2010). ABA perception and signaling. Trends Plant Sci. 15, 395-401. doi: 10.1016/j.tplants.2010.04.006

Rienmüller, F., Beyhl, D., Lautner, S., Fromm, J., Al-Rasheid, K. A. S., Ache, P., et al. (2010). Guard cell-specific calcium sensitivity of high density and activity SV/TPC1 channels. Plant Cell Physiol. 51, 1548-1554. doi: 10.1093/pcp/pcq102

Roelfsema, M., and Hedrich, R. (2010). Making sense out of $\mathrm{Ca}^{2+}$ signals: their role in regulating stomatal movements. Plant Cell Environ. 33, 305-321. doi: 10.1111/j.1365-3040.2009.02075.x

Roelfsema, M. R., Hedrich, R., and Geiger, D. (2012). Anion channels: master switches of stress responses. Trends Plant Sci. 17, 221-229. doi: 10.1016/j.tplants.2012.01.009

Saxena, I., Srikanth, S., and Chen, Z. (2016). Cross talk between $\mathrm{H}_{2} \mathrm{O}_{2}$ and interacting signal molecules under plant stress response. Front. Plant Sci. 7:570. doi: 10.3389/fpls.2016.00570

Scott, A. C., and Allen, N. S. (1999). Changes in cytosolic pH within Arabidopsis root Columella cells play a key role in the early signaling pathway for root gravitropism. Plant Physiol. 121, 1291-1298. doi: 10.1104/pp.121.4.1291

Siegel, R. S., Xue, S., Murata, Y., Yang, Y., Nishimura, N., Wang, A., et al. (2009). Calcium elevation-dependent and attenuated resting calciumdependent abscisic acid induction of stomatal closure and abscisic acid-induced enhancement of calcium sensitivities of S-type anion and inward-rectifying $\mathrm{K}^{+}$ channels in Arabidopsis guard cells. Plant J. 59, 207-220. doi: 10.1111/j.1365313X.2009.03872.x

Sokolovski, S., and Blatt, M. R. (2004). Nitric oxide block of outward-rectifying $\mathrm{K}^{+}$ channels indicates direct control by protein nitrosylation in guard cells. Plant Physiol. 136, 4275-4284. doi: 10.1104/pp.104.050344

Song, Y., Miao, Y., and Song, C. P. (2014). Behind the scenes: the roles of reactive oxygen species in guard cells. New Phytol. 201, 1121-1140. doi: 10.1111/nph.12565

Srivastava, N., Gonugunta, V. K., Puli, M. R., and Raghavendra, A. S. (2009). Nitric oxide production occurs downstream of reactive oxygen species in guard cells during stomatal closure induced by chitosan in abaxial epidermis of Pisum sativum. Planta 229, 757-765. doi: 10.1007/s00425-008-0855-5

Suhita, D., Raghavendra, A. S., Kwak, J. M., and Vavasseur, A. (2004). Cytosolic alkalinization precedes reactive oxygen species production during methyl jasmonate and abscisic acid-induced stomatal closure. Plant Physiol. 134, 1536-1545. doi: 10.1104/pp.103.032250

Sun, L. R., Hao, F. S., Lu, B. S., and Ma, L. Y. (2010). AtNOA1 modulates nitric oxide accumulation and stomatal closure induced by salicylic acid in Arabidopsis. Plant Signal. Behav. 5, 1022-1024. doi: 10.4161/psb.5.8.12293

Umezawa, T., Nakashima, K., Miyakawa, T., Kuromori, T., Tanokura, M., Shinozaki, K., et al. (2010). Molecular basis of the core regulatory network 
in ABA responses: sensing, signaling and transport. Plant Cell Physiol. 51, 1821-1839. doi: 10.1093/pcp/pcq156

Uraji, M., Katagiri, T., Okuma, E., Ye, W., Hossain, M. A., Masuda, C., et al. (2012). Cooperative function of PLD $\delta$ and PLD $\alpha 1$ in abscisic acid induced stomatal closure in Arabidopsis. Plant Physiol. 159, 450-460. doi: 10.1104/pp.112. 195578

Vavasseur, A., and Raghavendra, A. S. (2005). Guard cell metabolism and $\mathrm{CO}_{2}$ sensing. New Phytol. 165, 665-682. doi: 10.1111/j.1469-8137.2004. 01276.x

Wang, P., and Song, C. P. (2008). Guard-cell signalling for hydrogen peroxide and abscisic acid. New Phytol. 178, 703-718. doi: 10.1111/j.1469-8137.2008.02431.x

Wang, W. H., Yi, X. Q., Han, A. D., Liu, T. W., Chen, J., Wu, F. H., et al. (2011). Calcium-sensing receptor regulates stomatal closure through hydrogen peroxide and nitric oxide in response to extracellular calcium in Arabidopsis. J. Exp. Bot. 63, 177-190. doi: 10.1093/jxb/err259

Xie, Y., Mao, Y., Zhang, W., Lai, D., Wang, Q., and Shen, W. (2014). Reactive oxygen species-dependent nitric oxide production contributes to hydrogenpromoted stomatal closure in Arabidopsis. Plant Physiol. 165, 759-773. doi: $10.1104 /$ pp.114.237925

Ye, W., Hossain, M. A., Munemasa, S., Nakamura, Y., Mori, I. C., and Murata, Y. (2013). Endogenous abscisic acid is involved in methyl jasmonate-induced reactive oxygen species and nitric oxide production but not in cytosolic alkalization in Arabidopsis guard cells. J. Plant Physiol. 170, 1212-1215. doi: 10.1016/j.jplph.2013.03.011

Zhang, H., Fang, Q., Zhang, Z., Wang, Y., and Zheng, X. (2009). The role of respiratory burst oxidase homologues in elicitor-induced stomatal closure and hypersensitive response in Nicotiana benthamiana. J. Exp. Bot. 60, 3109-3122. doi: $10.1093 / \mathrm{jxb} / \mathrm{erp} 146$

Zhang, H., Wang, M., Wang, W., Li, D., Huang, Q., Wang, Y., et al. (2012). Silencing of $\mathrm{G}$ proteins uncovers diversified plant responses when challenged by three elicitors in Nicotiana benthamiana. Plant Cell Environ. 35, 72-85. doi: 10.1111/j.1365-3040.2011.02417.x
Zhang, W., Jeon, B. W., and Assmann, S. M. (2011). Heterotrimeric G-protein regulation of ROS signaling and calcium currents in Arabidopsis guard cells. J. Exp. Bot. 62, 2371-2379. doi: 10.1093/jxb/erq424

Zhang, W., Qin, C., Zhao, J., and Wang, X. (2004). Phospholipase D1derived phosphatidic acid interacts with ABI1 phosphatase $2 \mathrm{C}$ and regulates abscisic acid signaling. Proc. Natl. Acad. Sci. U.S.A. 101, 9508-9513. doi: 10.1073/pnas.0402112101

Zhang, X., Dong, F. C., Gao, J. F., and Song, C. P. (2001). Hydrogen peroxideinduced changes in intracellular $\mathrm{pH}$ of guard cells precede stomatal closure. Cell Res. 11, 37-43. doi: 10.1038/sj.cr.7290064

Zhang, Y., Zhu, H., Zhang, Q., Li, M., Yan, M., Wang, R., et al. (2009). Phospholipase $\mathrm{D} \alpha 1$ and phosphatidic acid regulate NADPH oxidase activity and production of reactive oxygen species in ABA-mediated stomatal closure in Arabidopsis. Plant Cell 21, 2357-2377. doi: 10.1105/tpc.108.062992

Zhao, X., Li, Y. Y., Xiao, H. L., Xu, C. S., and Zhang, X. (2013). Nitric oxide blocks blue light-induced $\mathrm{K}^{+}$influx by elevating the cytosolic $\mathrm{Ca}^{2+}$ concentration in Vicia faba guard cells. J. Integr. Plant Biol. 55, 527-536. doi: 10.1111/jipb.12038

Zhu, Y., Ge, X. M., Wu, M. M., Li, X., and He, J. M. (2014). The role and interactions of cytosolic alkalization and hydrogen peroxide in ultraviolet B-induced stomatal closure in Arabidopsis. Plant Sci. 215-216, 84-90. doi: 10.1016/j.plantsci.2013.11.010

Conflict of Interest Statement: The authors declare that the research was conducted in the absence of any commercial or financial relationships that could be construed as a potential conflict of interest.

Copyright $\odot 2016$ Agurla and Raghavendra. This is an open-access article distributed under the terms of the Creative Commons Attribution License (CC BY). The use, distribution or reproduction in other forums is permitted, provided the original author(s) or licensor are credited and that the original publication in this journal is cited, in accordance with accepted academic practice. No use, distribution or reproduction is permitted which does not comply with these terms. 